\title{
Runoilija lintujen tulkkina
}

\section{Karoliina Lummaa: Kui trittitii! Finnish Avian Poetics. Trans. Jaakko Mäntyjärvi (main text), Emily Jeremiah and Fleur Jeremiah (poems), photography Oskari Härmä and Ari Kuusela. Helsinki: Finnish Academy of Sciences and Letters 2017, $262 \mathrm{s.}$}

Lintupoetiikassa sekä runojen kirjoittamista että lukemista tarkastellaan yhteydessä todellisiin lintuihin. Linturunojen katsotaan syntyneen lintujen, ihmisten ja kielen yhteisvaikutuksesta. Näistä lähtökohdista käsin Karoliina Lummaa erittelee suomalaisten runojen lintuvaikutteita teoksessaan Kui trittitii! Finnish Avian Poetics. Runovalikoima ilmentää itsenäistä makua, sillä kyse on suurelta osin marginaaliin jääneistä teoksista; sitä paitsi aineiston karsimisen on täytynyt vaatia päättäväistä puntarointia. Toisesta maailmansodasta nykypäivään keskittyvä runojen kirjo tuo lukemiseen oman viehätyksensä; poeettiseen metsään mahtuu niin Eero Lyyvuon sykähdyttävän elinvoimaisia lintuääniä, Sauli Sarkasen tikkamaisia omakuvia kuin myös Antti Salmisen ritiseviä pesiä.

Tutkimuksen teoreettinen tausta käsittää muun muassa eläin- ja lintupoetiikkaa (Moe, Mason), aineellista ekokritiikkiä (Iovino \& Oppermann) ja taidemelua (Nechvatal). Yhtenä kirjan ansiona onkin ajankohtaisten suuntausten tuominen lukijan tietoisuuteen; jos aikaa ja kiinnostusta riittää, bibliografiasta voi poimia kirjan jatkoksi tuoreita ja innostavia lukuvinkkejä. Tiiviissä muodossa referoidut nykyteoriat herättävät kysymyksen, miten uutuudet suhteutuvat klassisiin oivalluksiin. Mielenkiintoista olisi suhteuttaa esimerkiksi ajatus runouden lintuvaikutteista aikojen saatossa esitettyihin näkemyksiin, joiden mukaan kirjoittaja on pelkkä välikappale, kääntäjä tai vastaanottaja.

Teoreettisia näkökantoja käydään kirjassa läpi paikoitellen melko dialektiseen tyyliin. Jäljittelyn käsite tyrmätään yhtäällä, vaikka toisaalla tunnustetaankin, ettei kukaan meistä jäljittelemättä osaisi edes omaa äidinkieltään. Muutamin paikoin teoreettiset oikotiet tuottavat päänvaivaa lukijalle, joka ei ole omaksunut kyseistä taustateoriaa. Vaikeinta on eläytyä oletuslukijaan, jonka dualistista maailmankuvaa aineellis-semioottisen käsite (Haraway) pyrkii horjuttamaan, ja siksi se tuntuu repivän irti toisistaan ulottuvuuksia, joita sen olisi määrä yhdistää. Ilman tarkempaa argumentointia on vaikea ymmärtää, mitä tarkoitusta lintujen ja runojen aineellisten ja semioottisten ominaisuuksien erittely palvelee. Sopii myös kysyä, voisiko "aineellisten" ominaisuuksien sijaan puhua vaikkapa fysikaalisista ominaisuuksista - onhan esimerkiksi äänessä kyse pikemminkin energiasta kuin aineesta. Terminologeja saattaisi häiritä se, että lintujen äänten transkriptiosta ja translitteraatiosta puhutaan sekaisin käsitteitä määrittämättä; toisaalta ymmärrettävyys ei tästä kärsi. 
Moniulotteisesta aiheesta kertovaa kirjaa voisi jatkaa loputtomiin; sikäli Lummaata voi onnitella siitä, että hän ei lähde koluamaan kaikkia mahdollisia sivupolkuja eikä lastaa tekstiin liikoja viittauksia, vaikka relevanttia kirjallisuutta alalla riittää. Lintunimien onomatopoeettisuudesta puhuttaessa voisi viitata Annu Marttilaan, joka on tehnyt aiheesta laajan kieltenvälisen vertailun. Mai Kuhan ekolingvistisen tutkimuksen kulkuneuvojen ja eläinten törmäyksistä voisi ottaa lukuun, kun käsitellään Jouni Tossavaisen runoa lintujen ja lentokoneen törmäyksestä. Käännöstutkimusta olisi mahdollista soveltaa varsinkin luvussa, jonka teemana on linnunlaulun kääntäminen kielelle, ja runoanalyyseja voisi kytkeä eksplisiittisesti eläintutkimuksen klassikkoteksteihin. Elliptinen ote stimuloi tutkimuskysymykseen perehtynyttä lukijaa ja keventää sellaisen lukijan työmuistia, jolle aihe on uusi.

Linturunous on syntynyt osittain lintujen vaikutuksesta, eikä sitä Lummaan mukaan pysty ymmärtämään ilman näitä. Lintutiedosta tulee avain runojen merkityksiin. Niinkin antropomorfinen päähänpisto kuin harmaapäätikan kateus vihertikkaa kohtaan loksahtaa evolutionaariseen viitekehykseen, kun ilmenee, että kirkkaampi vihreys voisi tuoda jälkimmäiselle kilpailuetua. Pian lukijakin huomaa soveltavansa runoihin biologian alkeita. Munan muotoinen tyhjä tila Tossavaisen runossa tuo mieleen, kuinka lintuemo havaitessaan munan kadonneen pesästä tuottaa uuden tilalle.

Tieteellisyydessäänkin Kui trittitii! tunnustaa poeettisen lähestymistavan vahvuudet. Linturunojen aistillinen puoli saa huomiota osiossa "Languages", ja osiossa "Beings" runous näyttäytyy tapana pysähtyä ihmettelemään toislajisten olemistapoja ja kuvittelemaan näiden kokemusmaailmoja. Runous täydentää tieteellistä lähestymistapaa kyseenalaistamalla sen lähtökohdat ja tekemällä näkyviksi lintuja rengastavan kädellisen naarmut. Monet käsitellyt runot myös saattavat lintujen elinehtoja koskevan tiedon muotoon, jossa ihmisten on helpompi kokea se merkityksellisenä.

Lajienvälistä viestintää on Lummaan mukaan tutkittu eniten zoosemiotiikan piirissä, vaikka monitieteisen alan tutkijoista vain murto-osa tunnustautunee semiootikoiksi. Tähän liittyen kirjassa esitetyt näkemykset edellytyksistämme ymmärtää toislajisia kuulostavat paikoitellen melko skeptisiltä, eikä tulkinnoissa oteta kantaa kognitiivisen etologian tai lajienvälisen viestinnän ja kielikoulutuksen edistysaskeliin. Teoreettisesta skeptisismistä huolimatta Lummaa asettuu herkkävaistoisesti runon höyheniin analyyseissaan, olipa sitten kyse hautovan emon huolista, rummuttavan tikan voitonriemusta tai ruumiin moniselitteisestä tyhjyydestä.

Kokonaisjäsennykseltään Kui trittitii! on tyylikäs, ja luontokulttuurisista lähtökohdistaan käsin kirja myös uudistaa kirjallisuudentutkimuksen esitystapaa. Alkusivun muna korostaa lintujen arvoituksellista poissaoloa kirjallisesta työstä, siirtymiä siivittävät upeat mustavalkoiset lintukuvat, ja väriliitteen lajiesittelyssä huuhkajan uhanalaisuusluokitusta säestää huomio, että lintu esiintyy vain harvoin suomalaisessa nykyrunoudessa. Lukijaa suositellaan myös 
tutustumaan runolintujen ääniin. Kuvineen, suomen- ja englanninkielisine runoineen ja lintukytköksineen Kui trittitiil'ssä on jotakin palapelimaista ja silti intuitiivisesti yhteenkuuluvaa. Kirja stimuloi ajattelua ja havahduttaa siihen, että linturunoja lukiessamme olemme perin ihmeellisten kysymysten äärellä. On helppo kuvitella, kuinka ilahduttava löytö Kui trittitii! on suomea taitamattomalle lintutunnelmoijalle.

\section{Ella Vihelmaa}

